\title{
Milk haptoglobin, milk amyloid $A$, and $N$-acetyl- $\beta$-D-glucosaminidase activity in bovines with naturally occurring clinical mastitis diagnosed with a quantitative PCR test
}

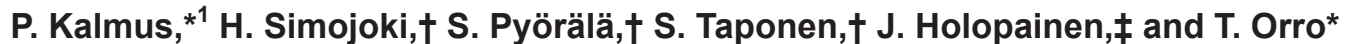 \\ *Department of Therapy, Institute of Veterinary Medicine and Animal Sciences, Estonian University of Life Sciences, Tartu, 51014, Estonia \\ †Department of Production Animal Medicine, Faculty of Veterinary Medicine, University of Helsinki, Leissantie 43, FI-04920 Saarentaus, Finland \\ †Finnzymes Oy, Keilaranta 16A, FI-02150 Espoo, Finland
}

\begin{abstract}
The associations between quantitative bacteriological results from a real-time PCR test and concentrations of acute-phase proteins (APP) and $N$-acetyl- $\beta$-Dglucosaminidase (NAGase) activity in milk in naturally occurring clinical mastitis were investigated. Milk APP concentrations and NAGase activity in clinical mastitis caused by different udder pathogens were studied. The associations between the severity of the clinical signs and concentrations of APP and NAGase activity were estimated. Milk samples from 281 cases of clinical mastitis were collected from 3 Estonian dairy farms and analyzed by PCR to identify pathogens. Twenty-seven samples out of $281(9.6 \%)$ were PCR negative. Milk samples containing 4 or more bacterial species ( $\mathrm{n}=$ 28) were considered possibly contaminated and excluded from all further analyses. In total, 443 bacterial identifications were made from the remaining 226 milk samples. A single bacterial species was detected in 68 samples (30.1\%), 2 species were detected in 99 samples (43.8\%), and 3 species were detected in 59 (26.1\%) samples. To determine the inflammatory response in the udder, the concentrations of milk amyloid A (MAA) and haptoglobin (Hp) and NAGase activity in the milk were analyzed. A significant positive association was found between the severity of the clinical signs and inflammatory markers in the milk. Milk amyloid $\mathrm{A}$ and $\mathrm{Hp}$ concentrations and NAGase activity were significantly higher in samples with large quantities of bacterial DNA from Escherichia coli or Streptococcus dysgalactiae compared with milk samples not containing those species. Large quantities of bacterial DNA from Trueperella pyogenes or Streptococcus uberis in the milk were associated with elevated concentrations of $\mathrm{Hp}$ and high NAGase activity, but not with increased MAA concentrations. Milk samples containing Corynebacte-
\end{abstract}

Received September 18, 2012.

Accepted February 12, 2013.

${ }^{1}$ Corresponding author: piret.kalmus@emu.ee rium bovis and coagulase-negative staphylococci had significantly lower concentrations of MAA and $\mathrm{Hp}$ and lower NAGase activity compared with samples where these species were not detected. It can be concluded that concentrations of APP and NAGase activity in the milk were associated with the quantity of bacterial DNA in the milk samples.

Key words: clinical mastitis, acute-phase protein, $N$-acetyl- $\beta$-D-glucosaminidase (NAGase) activity, realtime PCR

\section{INTRODUCTION}

Knowledge of the causative pathogens is required for appropriate control and treatment of mastitis. Bacterial culture has been the gold standard for mastitis diagnostics (NMC, 2004), but a commercial PCR-based method has been introduced as a routine method for detection of mastitis-causing bacteria (PathoProof Mastitis PCR Assay; Thermo Fisher Scientific, Espoo, Finland). Due to the greater sensitivity of the PCR test compared with the conventional methods, often resulting in detection of more species per sample, the interpretation of the PCR results is challenging (Koskinen et al., 2010). More research concerning the use and interpretation of PCR mastitis tests in routine use is warranted.

Mastitis-causing bacteria entering the udder quarter via the teat canal, establish IMI with varying degrees of tissue injury. Tissue injury and inflammation initiate an acute-phase response (APR), which most commonly begins by releasing inflammatory mediators from tissue macrophages or blood monocytes that gather at the site of damage (Baumann and Gauldie, 1994; Koj, 1996). An APR results in an increase in systemic and local concentrations of acute-phase proteins (APP). Two of those proteins, haptoglobin $(\mathbf{H p})$ and serum amyloid A, play a significant role in the early response of the mammary gland to pathogenic bacteria (Eckersall et al., 2001; Nielsen et al., 2004). Haptoglobin is diffused from blood into the milk, but also originates from milk 
leukocytes and epithelial cells in the mammary gland (Hiss et al., 2004). Serum amyloid A is secreted by hepatocytes and, in addition, the mammary gland epithelium appears to secrete a mammary gland-specific isoform mammary-associated serum amyloid A 3 (MSAA3) milk amyloid A (MAA; Eckersall et al., 2001).

Local APR in the udder have mostly been studied using experimental models in which pathogenic bacteria such as Escherichia coli (Hyvönen et al., 2006; Suojala et al., 2008; Larsen et al., 2010) or staphylococci (Grönlund et al., 2003; Simojoki et al., 2009) have been infused into the udder quarter. These studies showed that $E$. coli increases concentrations of APP in the milk to a greater extent than CNS or Staphylococcus aureus. A field study by Pyörälä et al. (2011) concluded that the concentrations of $\mathrm{Hp}$ and MAA in milk vary depending on which pathogens are isolated. Concentrations of APP were the highest in cases where mastitis was caused by $E$. coli and significantly lower when mastitis was caused by streptococci or Staph. aureus. Milk amyloid $\mathrm{A}$ and $\mathrm{Hp}$ inflammatory responses were very mild in mastitis caused by CNS. $N$-Acetyl- $\beta$-D-glucosaminidase (NAGase) is an intracellular, lysosomal enzyme that is released into milk from neutrophils during phagocytosis and cell lysis, but also from damaged epithelial cells, indicating udder tissue destruction (Kitchen et al., 1984). Milk NAGase activity correlates very closely with SCC and can be analyzed also from frozen milk samples (Kitchen et al., 1984).

The first objective of the study was to investigate associations between different quantities of bacterial DNA detected using a PCR-based method and concentrations of APP and NAGase activity in milk from bovines with naturally occurring clinical mastitis. The second aim was to compare milk APP concentrations and NAGase activity in clinical mastitis caused by different udder pathogens and to study the effect of the severity of clinical signs.

\section{MATERIALS AND METHODS}

\section{Milk Samples and Clinical Examination}

Milk samples from cows diagnosed with clinical mastitis were collected for a treatment study, which was conducted during the period 2007 to 2009 in Estonia. Milk samples originated from 3 different loose-housing dairy farms. Herd sizes ranged from 300 to 1,000 cows. Among those herds, annual mean milk production was 8,500 to $9,800 \mathrm{~kg}$, and the average bulk milk SCC was between 180,000 and 450,000 cells/mL. All herds were milked 3 times per day. Clinical mastitis was diagnosed by trained farm personnel at milking time. Clinical mastitis was defined according to the International Dairy Federation (IDF, 1999), which specifies that at least some visible signs should be present in the udder or in the milk. Systemic and local signs were recorded and categorized on a 3-point scale as follows: (1) mild clinical mastitis: milk from a quarter had abnormal viscosity (watery or thicker than normal), color (yellow or blood-tinged), or consistency (flakes or clots), but no udder swelling or systemic signs; (2) moderate clinical mastitis: similar to mild clinical mastitis, but with the addition of visible or palpable changes in the udder (swelling or pain) without systemic signs; and (3) severe clinical mastitis: both local and systemic signs (fever above $39.2^{\circ} \mathrm{C}$ ). All cow data (affected quarter, score of clinical mastitis, age, and DIM) were recorded.

Once clinical mastitis was diagnosed, a milk sample from the diseased udder quarter was collected for bacteriological examination. Before collection, the teat end was cleaned with $70 \%$ ethanol swabs and allowed to dry. After discarding a few streams of milk, samples (2 to $4 \mathrm{~mL}$ ) were collected into sterile $10-\mathrm{mL}$ plastic tubes and frozen at $-20^{\circ} \mathrm{C}$ until further investigation. Only 1 diagnosed case of clinical mastitis per cow was included in the study.

During the study period, milk samples were collected from 35 cows at farm 1, 123 cows at farm 2, and 105 cows at farm 3; a total of 281 quarter milk samples from 263 cows were included. Eighteen cows had 2 affected quarters.

\section{Real-Time PCR Assay}

A commercial real-time PCR test kit (PathoProof Mastitis PCR Assay; Thermo Fisher Scientific) was used for direct analysis of all milk samples. The kit protocol involved 4 separate multiplex real-time PCR reactions, which targeted 11 bacterial species and groups (covering more than 25 mastitis-causing species in total): Staphylococcus spp. (including Staph. aureus and all relevant CNS species), Enterococcus spp. (including Enterococcus faecalis and Enterococcus faecium), Corynebacterium bovis, E. coli, Streptococcus dysgalactiae, Streptococcus agalactiae, Streptococcus uberis, Trueperella (formerly Arcanobacterium) pyogenes/Peptoniphilus indolicus (Yassin et al., 2011), Klebsiella spp. (including Klebsiella oxytoca and Klebsiella pneumoniae), and Serratia marcescens. The testing was done according to the user's manual and described by Koskinen et al. (2010). Based on the cycle threshold (Ct) values, the bacterial DNA quantity in each targeted bacterial species was grouped into 3 classes: small quantity $(+)$, intermediate quantity $(++)$, or large quantity $(+++)$, according to the manufacturer's manual. 


\section{Analytical Methods for Determination of Inflammatory Response in Milk}

The concentration of MAA in milk was determined using a commercial ELISA kit (Phase MAA Assay Kit; Tridelta Development Ltd., Maynooth, Co. Kildare, Ireland). Milk samples were initially diluted to 1:500. If the concentration was above the range of a standard curve, they were further diluted as necessary. For very high MAA values, milk samples were diluted up to $1: 10,000$ (maximum concentration $1,500 \mathrm{mg} / \mathrm{L}$ ). A 1:100 dilution was used (minimum concentration 0.94 $\mathrm{mg} / \mathrm{L}$ ) for very low values. Intra- and interassay coefficients of variation were $<13$ and $<12 \%$, respectively.

Milk Hp concentrations $(\mathrm{mg} / \mathrm{L})$ were determined by a method based on the ability of $\mathrm{Hp}$ to bind to hemoglobin (Makimura and Suzuki, 1982) and using tetramethylbenzidine as a substrate (Alsemgeest et al., 1994). The assay is meant to determine concentrations of $\mathrm{Hp}$ in the serum, but was adapted here to be used for milk, as described by Hyvönen et al. (2006). Optical densities of the formed complex were measured at $450 \mathrm{~nm}$ using a spectrophotometer. Lyophilized bovine acute-phase serum was used as a standard, and calibration was carried out according to the European Union concerted action on the standardization of animal APP (number QLK5-CT-1999-0153). The working range of the assay was 60 to $1,900 \mathrm{mg} / \mathrm{L}$. The interassay and intraassay coefficient of variation values for $\mathrm{Hp}$ analysis were $<8$ and $<13 \%$, respectively.

\section{Milk NAGase Activity Determination}

Milk NAGase activity was measured by a fluoro-optical method using an in-house microplate modification developed by Mattila and Sandholm (1985) and further modified by Hovinen et al. (2010). The calibrated milk sample was replaced with a control milk sample with a known 4-methyl-umbelliferon (4-MU) concentration, and NAGase activity was expressed as picomoles of $4-\mathrm{MU} / \mathrm{min}$ per microliter of milk at $25^{\circ} \mathrm{C}$. The upper detection limit for NAGase activity was 24.5 pmol of $4-\mathrm{MU} / \mathrm{min}$ per microliter. Interassay and intraassay coefficients of variation for NAGase activity were 5 and $4 \%$, respectively.

\section{Statistical Analysis}

Stata 10.0 (StataCorp, TX) software was used for statistical analyses. Only milk samples with PCRnegative results or $\leq 3$ pathogen species were analyzed $(\mathrm{n}=253)$. Generalized linear mixed models (GLMM) were used to investigate associations between milk APP and PCR results. The outcome variable MAA was loga- rithmically transformed, and the inverse square root transformation of $\mathrm{Hp}$ was used. As Hp is evaluated using a model in inverse scale, negative model estimates represent higher $\mathrm{Hp}$ concentrations. The full models included lactation number as a 4-level categorical variable (1, 2, 3, and $\geq 4$ lactations), DIM was categorized as a 4-level variable according to quartiles (1-19, 20-59, 60-118, and 119-412 DIM), farm as a 3-level variable, and affected quarter as a 2-level variable (fore and hind quarters). These variables were kept in all models to control possible confounding effects. As these variables were not significant in any of the models (except affected quarters in the MAA model), they are not shown in our results. The PCR results by pathogen were included as categorical variables (negative,,+++ , or +++ ). If PCR results were under 6 cases per level, they were consolidated with the previous factor level as follows: C. bovis ++ with C. bovis +; Strep. agalactiae +++ with Strep. agalactiae ++ ; Strep. dysgalactiae +++ with Strep. dysgalactiae $++;$ T. pyogenes +++ with T. pyogenes ++ ; and CNS +++ with CNS ++ . To account for clustering of data (13 cows had 2 samples from different quarters), cow was included as random factor. The Wald test was used to evaluate the overall significance of the categorical variables with more than 2 levels. Nonsignificant PCR result variables were removed using the stepwise backward elimination procedure. Both final models were tested for interactions between minor pathogens $(C$. bovis and CNS) and major pathogens (E. coli, T. pyogenes, Strep. uberis, and Strep. dysgalactiae).

The random effects Tobit regression model for censored data was used to investigate associations between milk NAGase activity and PCR results. The Tobit regression model was chosen because $>40 \%$ of the NAGase results were over the maximum working limit of the assay (24.5 pmol of 4-MU/min per microliter), which would violate the regression model's assumptions. In the Tobit regression, all cases falling above (or below) a specified threshold value are censored, although these cases remain in the analysis (Long, 1997). A more detailed explanation using Tobit regression for analyzing milk NAGase activity data are given in Pyörälä et al. (2011). Square root transformation of milk NAGase activities was used to achieve a normal distribution of uncensored data; 104 samples were censored at the level of $24.5 \mathrm{pmol}$ of $4-\mathrm{MU} / \mathrm{min}$ per microliter. All other model building strategies and variables in each model were as described for the APP models above.

A linear regression model for APP and a Tobit regression model for NAGase were used to investigate the associations of milk APP concentrations and milk NAGase activities with the severity of clinical mastitis (mild, moderate, and severe signs). Assumptions of all 
Table 1. Bacterial DNA quantities of udder pathogens detected in 226 milk samples from cases of cows with naturally occurring clinical mastitis ${ }^{1}$

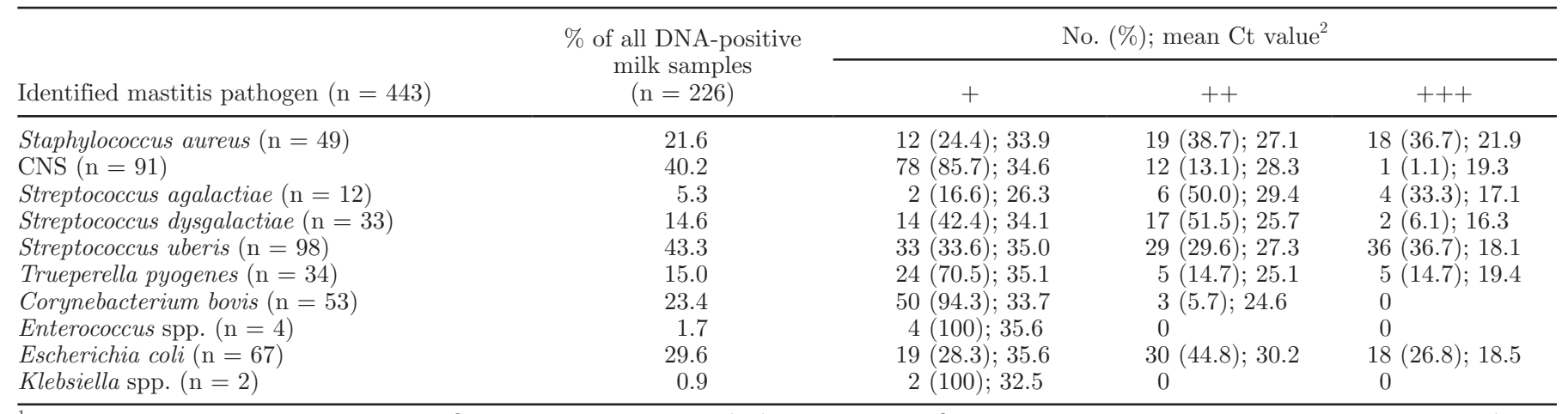

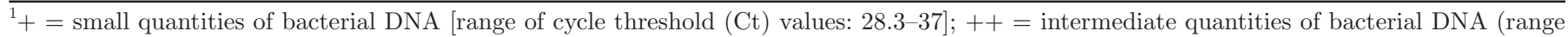
of Ct values: 22.1-33.7); $+++=$ large quantities of bacterial DNA (range of Ct values: 13.4-27.4).

${ }^{2}$ Cycle threshold values of each pathogen were based on the quantity of bacterial DNA.

models were controlled using normality and scatter plots of model residuals.

\section{RESULTS}

\section{Bacteriological Findings}

Ten different species of udder pathogens were detected in the 281 quarter milk samples using the real-time PCR kit. A total of 27 milk samples (9.6\%) were PCR negative, and $254(90.4 \%)$ samples contained DNA of at least 1 target species. Milk samples containing DNA of 4 or more bacterial species $(\mathrm{n}=28)$ were considered possibly contaminated and excluded from further analysis. In total, 443 bacterial identifications were made from the remaining 226 milk samples. A single bacterial species was found in $68(30.1 \%), 2$ species were found in $99(40.8 \%)$, and 3 species were found in $59(26.1 \%)$ of the DNA-positive milk samples.

The most prevalent bacterial species among the milk samples containing a single pathogen were Strep. uberis $(\mathrm{n}=20 ; 29.4 \%)$, Staph. aureus $(\mathrm{n}=14 ; 20.5 \%)$, and $E$. coli $(\mathrm{n}=13 ; 19.1 \%)$. Streptococcus uberis was detected in $45(45.4 \%)$ and CNS was detected in $40(40.4 \%)$ of the milk samples with 2 bacterial species.

Different quantities and proportions of mastitis-causing bacteria were detected in the milk samples (Table 1 ). None of the milk samples contained 2 or 3 bacterial species in large quantities simultaneously. Of the 98 milk samples containing DNA from CNS, the quantity was small $(+)$ in 78 of them $(85.7 \%)$. Bacterial DNA from Enterococcus spp. and Klebsiella spp. was detected rarely and only in small quantities.

\section{Clinical Signs, APP, and NAGase Activity in Milk}

In a total of 253 analyzed mastitis cases, $63.6 \%$ (n $=161)$ exhibited mild clinical signs and $31.2 \%(\mathrm{n}=$
79) moderate clinical signs. Severe clinical signs were recorded in $5.1 \%(\mathrm{n}=13)$ of the cases. All samples collected from cows with severe mastitis were positive for bacteria, and E. coli was detected in 10 of the 13 samples. Streptococcus uberis and CNS were the main bacterial species in moderate and mild clinical mastitis. Clinical signs in the cows yielding PCR-negative samples were moderate or mild.

The concentration of MAA in milk ranged between 0.94 and $1,500 \mathrm{mg} / \mathrm{L}$ [median: $43.3 \mathrm{mg} / \mathrm{L}$; interquartile range (IQR): $16.9-183.3 \mathrm{mg} / \mathrm{L}]$, and $\mathrm{Hp}$ varied from 59 to $1,890 \mathrm{mg} / \mathrm{L}$ (median: $214.1 \mathrm{mg} / \mathrm{L}$; IQR: 105.7-398.6). Of the 253 milk samples, 2 samples contained an MAA concentration below the working limits of the assay, and 13 samples contained an MAA concentration above the working limits of the assay $(0.94$ and $1,500 \mathrm{mg} / \mathrm{L}$, respectively). Twenty-one samples had Hp concentrations under the working limit of the assay $(59 \mathrm{mg} / \mathrm{L})$. The activity of NAGase in milk ranged between 0.53 and $24.5 \mathrm{pmol}$ of $4-\mathrm{MU} / \mathrm{min}$ per microliter (median: 19.5 pmol of 4-MU/min per microliter; IQR: 7.9-24.5 pmol of 4-MU/min per microliter), and in 104 milk samples, the NAGase activity was above the working range of the assay (24.5 pmol of $4-\mathrm{MU} / \mathrm{min}$ per microliter).

An association between the severity of clinical signs and the concentrations of APP and NAGase activity in the milk was found. In cases of severe clinical mastitis, MAA and Hp concentrations and NAGase activity values were significantly higher compared with cases of clinical mastitis with mild or moderate signs $(P<$ $0.001, P=0.006$, and $P=0.021$, respectively). Concentrations of MAA and $\mathrm{Hp}$ and NAGase activity in milk from cows with moderate clinical mastitis were significantly higher than values measured in milk from cows with mild clinical signs $(P<0.001, P=0.007$, and $P<0.001$, respectively).

Descriptive statistics of APP concentrations and NAGase activities in milk samples from clinical mas- 
Table 2. Concentrations of milk amyloid A (MAA), haptoglobin (Hp), and $N$-acetyl- $\beta$-D-glucosaminidase (NAGase) activity in milk samples from cows with clinical mastitis $(\mathrm{n}=147)^{1}$

\begin{tabular}{|c|c|c|c|}
\hline \multirow[b]{2}{*}{ Pathogen } & \multicolumn{3}{|c|}{ Median (minimum; maximum) value } \\
\hline & MAA (mg/L) & $\operatorname{Hp}(\mathrm{mg} / \mathrm{L})$ & $\begin{array}{l}\text { NAGase activity } \\
(\mathrm{pmol} \text { of } 4-\mathrm{MU} / \mathrm{min} \\
\text { per microliter })^{2}\end{array}$ \\
\hline Staphylococcus aureus $(\mathrm{n}=18)$ & $35.8(6.7 ; 1,500)$ & $201.1(59.0 ; 756.2)$ & $22.5(2.7 ; 24.5)$ \\
\hline $\mathrm{CNS}^{3}(\mathrm{n}=11)$ & $29.2(8.5 ; 1,500)$ & $123(59.0 ; 775.5)$ & $11.86(6.6 ; 24.5)$ \\
\hline Streptococcus agalactiae $(\mathrm{n}=4)$ & $53.5(28.9 ; 735.7)$ & $295.5(172.1 ; 506.1)$ & $20.6(6.6 ; 24.5)$ \\
\hline Trueperella pyogenes $(\mathrm{n}=10)$ & $25.6(0.95 ; 348.9)$ & $618.5(5.0 ; 1,155.8)$ & $24.5(1.73 ; 24.5)$ \\
\hline Corynebacterium bovis $^{4}(\mathrm{n}=4)$ & $12.4(0.09 ; 107.3)$ & $95.8(59.0 ; 108.6)$ & $9.9(0.5 ; 14.7)$ \\
\hline Escherichia coli $(\mathrm{n}=18)$ & $394.1(1.75 ; 1,500)$ & $575.4(59.0 ; 1,288.1)$ & $24.5(2.5 ; 24.5)$ \\
\hline PCR negative $(\mathrm{n}=27)$ & $23.2(7.4 ; 152.2)$ & $164.1(59.0 ; 548.3)$ & $9.2(1.3 ; 24.5)$ \\
\hline
\end{tabular}

${ }^{1}$ Only milk samples with 1 bacterial species only or 1 bacterial species in large quantity $(+++)$ are included in the table.

${ }^{2} 4$-MU $=4$-methyl-umbelliferon.

${ }^{3}$ Milk samples where only bacterial DNA of small/intermediate quantity $(+/++)$ of CNS was detected.

${ }^{4}$ Milk samples where only bacterial DNA of $C$. bovis $+/++$ was detected.

titis is presented in Table 2. Associations between the concentrations of APP and NAGase activities in the milk and the PCR results are presented in Tables 3, 4, and 5. Concentrations of $\mathrm{Hp}$ and MAA and NAGase activity in the milk were not affected by farm, lactation number, or DIM $(P>0.05$; data not shown). The affected quarter (fore or hind) did not affect the Hp concentrations or the NAGase activities in milk $(P>0.05$; data not shown). Significantly higher concentrations of MAA were found in the hind quarters compared with the fore quarters (Table 3 ).

Haptoglobin and MAA concentrations and NAGase activity in the milk were significantly higher when $E$. coli ++ and +++ or Strep. dysgalactiae $++/+++$ were detected, compared with all other milk samples where these species were not detected. In addition, a small quantity $(+)$ of $E$. coli in milk samples was associated with an elevated NAGase activity and MAA concentration. The presence of T. pyogenes at high levels in milk samples caused a significant elevation in Hp concentration, as well as an increased NAGase activity in the milk $(P<0.001$ and $P<0.001$, respectively) compared with milk samples without $T$. pyogenes. However, no association between the MAA concentration and the presence of $T$. pyogenes was found $(P>0.05$; data not shown). Milk samples containing DNA from $C$. bovis or

Table 3. Final generalized linear mixed model (GLMM) of associations between the concentration of milk amyloid A (MAA) in the milk and the pathogens detected with PCR $(n=253)$ from cows with naturally occurring clinical mastitis

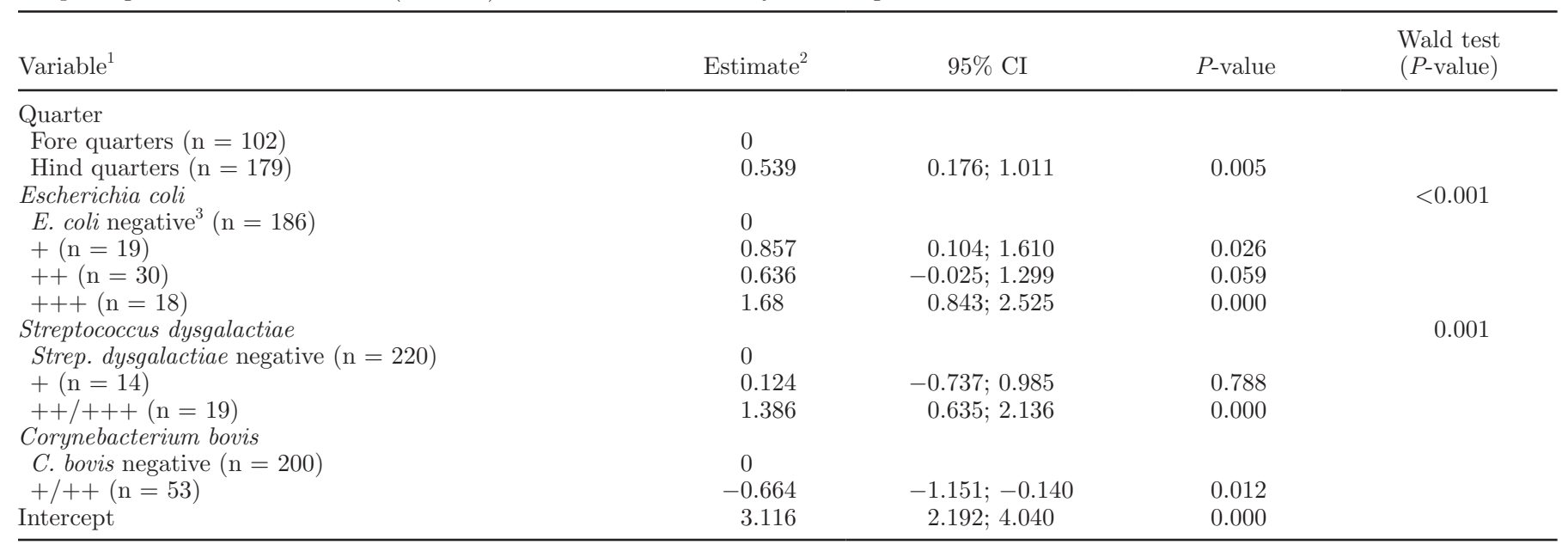

${ }^{1}+=$ small quantities of bacterial DNA; $++=$ intermediate quantities of bacterial DNA; $+++=$ large quantities of bacterial DNA.

${ }^{2}$ Estimates are on a logarithmic scale.

${ }^{3}$ Number of milk samples not containing DNA from detected bacteria. 
Table 4. Final generalized linear mixed model (GLMM) of associations between concentration of haptoglobin (Hp) in the milk and the pathogens detected with PCR $(\mathrm{n}=253)$ from cows with naturally occurring clinical mastitis

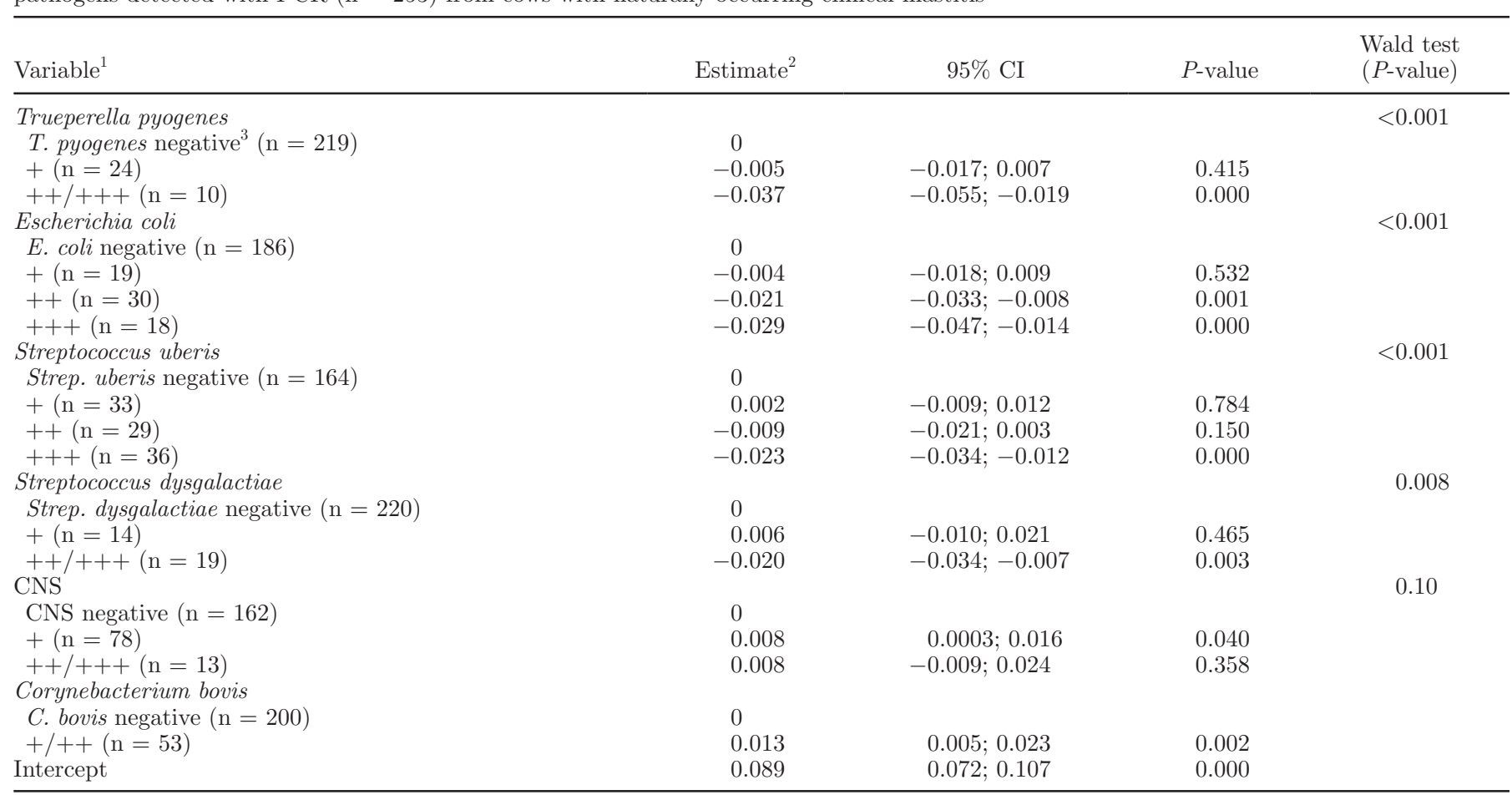

${ }^{1}+=$ small quantities of bacterial DNA; $++=$ intermediate quantities of bacterial DNA; $+++=$ large quantities of bacterial DNA.

${ }^{2}$ Estimates are on an inverse square root scale (negative estimate means higher concentration of $\mathrm{Hp}$ ).

${ }^{3}$ Number of milk samples not containing DNA from detected bacteria.

a small quantity of DNA from CNS had a significantly lower concentration of APP and lower NAGase activity compared with all other milk samples where other species were detected.

No interaction was detected in the models between minor (C. bovis and CNS) and major (E. coli, Strep. dysgalactiae, T. pyogenes, and Strep. uberis) pathogens. This means that any association between major pathogen DNA and the concentrations of the inflammatory markers was not influenced by the presence of minor pathogen DNA in the milk samples.

\section{DISCUSSION}

This study describes the associations between concentrations of APP in the milk and PCR-based bacteriological findings in cases of clinical mastitis. The amount of bacterial DNA detected in the samples from mastitis caused by certain species was associated with MAA and Hp concentrations and NAGase activity in the milk. The highest concentrations of MAA and the highest NAGase activities in milk were found in cows with large quantities of $E$. coli in their milk. This is in accordance with experimental studies showing a strong inflammatory response to E. coli (Hyvönen et al., 2006;
Suojala et al., 2008). Wenz et al. (2010) found that the concentration of Hp was the highest in E. coli-induced mastitis compared with mastitis caused by environmental streptococci or CNS. However, even small quantities of $E$. coli resulted in elevated concentrations of MAA and increased NAGase activity in the milk. Experimental studies have shown that even a small quantity of $E$. coli can induce an acute inflammatory reaction in the udder (Frost et al., 1982). Escherichia coli bacteria are generally eliminated rapidly from the udder, but trigger a strong inflammatory reaction, which is mainly due to endotoxin (Burvenich et al., 2003). In practice, the time of sampling after the onset of clinical mastitis could also influence the quantity of DNA of E. coli in the milk. Sampling late during the course of infection could explain the small quantity of $E$. coli detected in bacteriological examination, despite a strong inflammatory response.

Our findings support the results reported by Pyörälä et al. (2011), who found that higher concentrations of Hp and NAGase corresponded to the detection of $T$. pyogenes in mastitic milk samples but could establish no association between T. pyogenes and MAA. This could indicate that IMI due to $T$. pyogenes does not induce significant local production of MAA. Release of 
Table 5. Random effects Tobit regression model of associations between $N$-acetyl- $\beta$-D-glucosaminidase (NAGase) activity in the milk and the pathogens detected with PCR $(\mathrm{n}=253)$ from cows with naturally occurring clinical mastitis

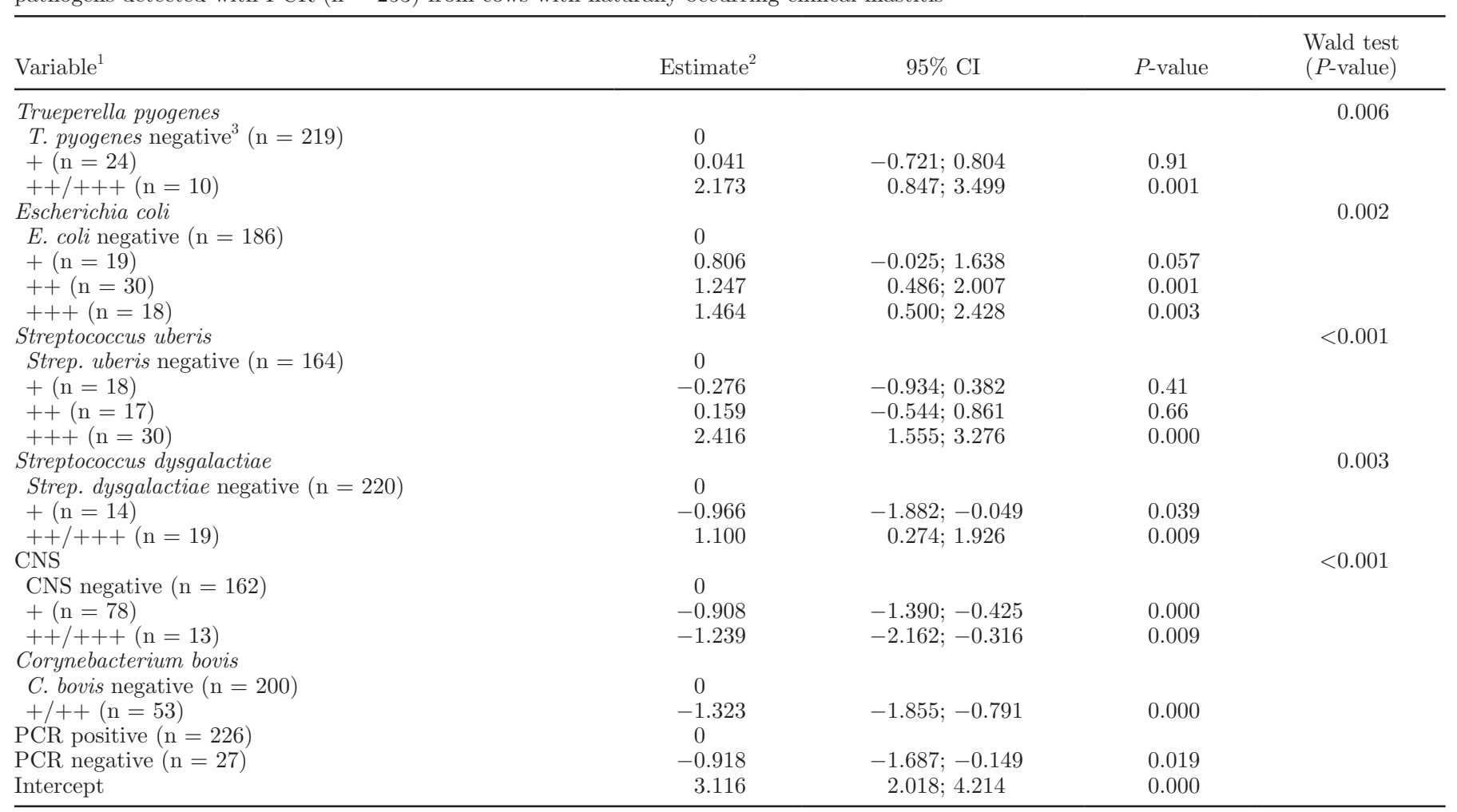

${ }^{1}+=$ small quantities of bacterial DNA $;++=$ intermediate quantities of bacterial DNA; $+++=$ large quantities of bacterial DNA.

${ }^{2}$ Estimates are on a square root scale.

${ }^{3}$ Number of milk samples not containing DNA from detected bacteria.

different APP may depend on the pathogens present. The major producers of $\mathrm{Hp}$ and NAGase in milk are neutrophils and epithelial cells, whereas only mammary gland epithelial cells appear to secrete MAA in cows with mastitis (Kitchen et al., 1984; Eckersall et al., 2006; Lai et al., 2009). Epithelial damage may manifest differently in different infections, which in turn could affect MAA concentrations in the milk.

The presence of Staph. aureus in the udder increased the concentrations of APP and the NAGase activity in the milk less than other major pathogens, indicating a mild inflammatory response in this infection. In experimentally induced Staph. aureus mastitis, the concentrations of $\mathrm{Hp}$ and MAA ranged between 52 and 323 $\mathrm{mg} / \mathrm{dL}$ and between 34 and $286 \mathrm{mg} / \mathrm{dL}$, respectively (Grönlund et al., 2003), and were lower than those found in experimentally induced Strep. uberis or E. coli mastitis (Pedersen et al., 2003; Suojala et al., 2008). Concentrations of Hp and MAA and NAGase activity in naturally acquired Staph. aureus mastitis were also lower than in streptococcal or E. coli mastitis (Pyörälä et al., 2011). In the present study, mastitis caused by Staph. aureus may have been very mild, which could explain the weak inflammatory response detected in the udder quarters. A small quantity of Staph. aureus DNA in the milk samples could also indicate that the bacteria were just skin contaminants and not the actual cause of the mastitis (Haveri et al., 2008).

In the present study, CNS and C. bovis were common bacterial species detected, mainly in small quantities, in milk samples positive for several species. C. bovis and CNS were the main pathogens detected using PCR from milk samples without growth (Taponen et al., 2009) and in the study by Koskinen et al. (2010) comparing conventional bacterial culturing and PCR in mastitis milk diagnostics. The frequent detection of these bacteria may be due to their extramammary origin. Corynebacterium bovis and CNS are generally considered to be opportunistic bacteria inhabiting teat skin and canals (Taponen et al., 2008). Nevertheless, the presence of CNS and C. bovis in the milk samples alone could increase concentrations of APP and NAGase activity in the milk, indicating that these bacteria are able to invade the udder and induce an inflammatory reaction. The PCR method allows the quantitative detection of udder pathogens and is especially useful 
when bacteria are present in small quantities and may be undetectable using conventional methods. On the other hand, the high sensitivity of the PCR analysis and the methods used to collect milk samples can cause false-positive results, especially in large herds when many staff members are involved in the sampling. The presence of microbes in a milk sample does not necessarily prove that those microbes caused the IMI. Interpretation of PCR results can be challenging and needs more guidance, even though PCR-based diagnostics are already in routine use in some countries. In the interpretation of PCR results, detection of a single species, preferably in moderate or large quantities, or detection of one dominating species with some other species provides a likely bacteriological diagnosis. The final diagnosis of mastitis always requires a full complement of supporting information, such as knowledge of the clinical signs and inflammation in the quarter (Pyörälä, 2012).

In the present study, Hp performed better than MAA in describing bovine inflammatory response. A constant increase in concentrations of $\mathrm{Hp}$ in the milk along with increasing quantities of DNA (except CNS and C. bovis) was observed. Haptoglobin could, thus, be a better marker than MAA for indicating the local inflammatory response in clinical mastitis caused by different pathogens.

\section{CONCLUSIONS}

The quantity of bacterial DNA in milk samples was associated with concentrations of APP and NAGase activity in the milk. These indicators reflect the inflammatory reaction in the mammary gland, and their concentrations increased with increasing severity of mastitis. Concentrations of APP and NAGase activity in milk significantly differed between different mastitiscausing bacterial species. Indicators of inflammation in milk, such as APP concentration and NAGase activity, may be useful to complete and support the bacteriological diagnosis of mastitis.

\section{ACKNOWLEDGMENTS}

This study was supported by the Research Foundation of Veterinary Medicine (Helsinki, Finland) and by the Walter Ehrström Foundation (Helsinki, Finland). Additional financial support was provided by the Estonian Ministry of Agriculture (Tallinn, Estonia; research contract 8-2/T8010) and the Estonian Ministry of Education (Tartu, Estonia; research project 8-2/T9001). Invaluable help of personnel from participating farms is deeply appreciated.

\section{REFERENCES}

Alsemgeest, S. P. M., H. C. Kalsbeek, T. Wensing, J. P. Koeman, A. M. van Ederen, and E. Gruys. 1994. Concentration of serum amyloid A (SAA) and haptoglobin (Hp) as parameters of inflammatory diseases in cattle. Vet. Q. 16:21-23.

Baumann, H., and J. Gauldie. 1994. The acute phase response. Immunol. Today 15:74-80.

Burvenich, C., V. Van Merris, J. Mehrzad, A. Diez-Fraile, and L. Duchateau. 2003. Severity of $E$. coli mastitis is mainly determined by cow factors. Vet. Res. 34:521-564.

Eckersall, P. D., F. J. Young, C. McComb, C. J. Hogarth, S. Safi, A. Weber, T. McDonald, A. M. Nolan, and J. L. Fitzpatrick. 2001. Acute phase proteins in serum and milk from dairy cows with clinical mastitis. Vet. Rec. 148:35-41.

Eckersall, P., F. J. Young, A. M. Nolan, C. H. Knight, C. McComb, M. M. Waterston, C. J. Hogarth, E. M. Scott, and J. L. Fitzpatrick. 2006. Acute phase proteins in bovine milk in an experimental model of Staphylococcus aureus subclinical mastitis. J. Dairy Sci. 89:1488-1501.

Frost, A. J., A. W. Hill, and B. E. Brooker. 1982. Pathogenesis of experimental bovine mastitis following a small inoculum of Escherichia coli. Res. Vet. Sci. 33:105-112.

Grönlund, U., C. Hultén, P. D. Eckersall, C. Hogarth, and K. Persson Waller. 2003. Haptoglobin and serum amyloid A in milk and serum during acute and chronic experimentally induced Staphylococcus aureus mastitis from dairy cows with chronic sub-clinical mastitis. J. Dairy Res. 70:379-386.

Haveri, M., M. Hovinen, A. Roslöf, and S. Pyörälä. 2008. Molecular types and genetic profiles of Staphylococcus aureus strains isolated from bovine intramammary infections and extramammary sites. J. Clin. Microbiol. 46:3728-3735.

Hiss, S., M. Mielenz, M. R. Bruckmaier, and H. Sauerwein. 2004. Haptoglobin concentration in blood and milk after endotoxin challenge and quantification of mammary $\mathrm{Hp}$ mRNA expression. J. Dairy Sci. 87:3778-3784.

Hovinen, M., H. Simojoki, R. Pösö, J. Suolaniemi, and S. Pyörälä. 2010. N-Acetyl- $\beta$-D-glucosaminidase activity in normal cow milk. In the 8th European Colloquium on acute phase proteins, Helsinki, Finland. University of Helsinki, Finland.

Hyvönen, P., L. Suojala, T. Orro, J. Haaranen, O. Simola, C. Røntved, and S. Pyörälä. 2006. Transgenic cows that produce recombinant human lactoferrin in milk are not protected from experimental Escherichia coli intramammary infection. Infect. Immun. 74:6206-6212.

IDF (International Dairy Federation). 1999. Suggested interpretation of mastitis terminology. Bull. Int. Dairy Fed. 338:3-26.

Kitchen, B. J., W. Seng Kwee, G. Middleton, and R. J. Andrews. 1984. Relationship between the level of N-acetyl- $\beta$-D-glucosaminidase (NAGase) in bovine milk and the presence of mastitis pathogens. J. Dairy Res. 51:11-16.

Koj, A. 1996. Initiation of acute phase response and synthesis of cytokines. Biochim. Biophys. Acta 1317:84-94.

Koskinen, M. T., G. J. Wellenberg, O. C. Sampimon, J. Holopainen, A. Rothkamp, L. Salmikivi, W. A. van Haeringen, T. J. G. M. Lam, and S. Pyörälä. 2010. Field comparison of real-time polymerase chain reaction and bacterial culture for identification of bovine mastitis bacteria. J. Dairy Sci. 93:5707-5715.

Lai, I.-H., J. H. Tsao, Y. P. Lu, J. W. Lee, X. Zhao, F. L. Chien, and S. J. T. Mao. 2009. Neutrophils as one of major haptoglobin sources in mastitis affected milk. Vet. Res. 40:17.

Larsen, T., C. M. Røntved, K. L. Ingvartsen, L. Vels, and M. Bjerring. 2010. Enzyme activity and acute phase proteins in milk utilized as indicators of acute clinical E. coli LPS-induced mastitis. Animal 4:1672-1679

Long, J. S. 1997. Regression Models for Categorical and Limited Dependent Variables. Sage Publications Inc., Thousand Oaks, CA.

Makimura, S., and N. Suzuki. 1982. Quantitative determination of bovine serum haptoglobin and it elevation in some inflammatory diseases. Nippon Juigaku Zasshi 44:15-21. 
Mattila, T., and M. Sandholm. 1985. Antitrypsin and N-acetyl- $\beta-D-$ glucosaminidase as markers of mastitis in herd of Ayrshire cows. Am. J. Vet. Res. 46:2453-2456.

Nielsen, B. H., S. Jacobsen, P. H. Andersen, T. A. Niewold, and P. M. H. Heegaard. 2004. Acute phase protein concentrations in serum and milk from healthy cows, cows with clinical mastitis and cows with extramammary inflammatory conditions. Vet. Rec. 154:361-365

NMC (National Mastitis Council). 2004. Microbiological Procedures for the Diagnosis of Bovine Udder Infection and Determination of Milk Quality. 4th ed. NMC, Madison, WI.

Pedersen, L. H., B. Aalbæk, C. M. Røntved, K. L. Ingvartsen, N. S. Sorensen, P. M. H. Heegaard, and H. E. Jensen. 2003. Early pathogenesis and inflammatory response in experimental bovine mastitis due to Streptococcus uberis. J. Comp. Pathol. 128:156-164.

Pyörälä, S. 2012. Letter to the editor: Comments on Schwaiger et al. (2012). J. Dairy Sci. 95:4185.

Pyörälä, S., M. Hovinen, H. Simojoki, J. Fitzpatrick, P. D. Eckersall, and T. Orro. 2011. Acute phase proteins in milk in naturally acquired bovine mastitis caused by different pathogens. Vet. Rec. 168:535.

Simojoki, H., T. Orro, and S. Pyörälä. 2009. Bovine experimental infection induced by coagulase-negative staphylococci. Vet. Microbiol. 134:95-99.
Suojala, L., T. Orro, H. Järvinen, J. Saatsi, and S. Pyörälä. 2008 Acute phase response in two consecutive experimentally induced E. coli intramammary infections in dairy cows. Acta Vet. Scand. $50: 18$.

Taponen, S., J. Björkroth, and S. Pyörälä. 2008. Coagulase-negative staphylococci isolated from bovine extramammary sites and intramammary infections in a single dairy herds. J. Dairy Res. $75: 422-429$.

Taponen, S., L. Salmikivi, H. Simojoki, T. Koskinen, and S. Pyörälä. 2009. Real-time polymerase chain reaction-based identification of bacteria in milk samples from bovine clinical mastitis with no growth in conventional culturing. J. Dairy Sci. 92:2610-2617.

Wenz, J. R., L. K. Fox, F. J. Muller, M. Rinaldi, R. Zeng, and D. D. Bannerman. 2010. Factors associated with concentrations of select cytokine and acute phase proteins in dairy cows with naturally occurring clinical mastitis. J. Dairy Sci. 93:2458-2470.

Yassin, A. F., H. Hupfer, C. Siering, and P. Schumann. 2011. Comparative chemotaxonomic and phylogenetic studies on the genus Arcanobacterium Collins et al. 1982 emend. Lehnen et al. 2006: Proposal for Trueperella gen. nov. and emended description of the genus Arcanobacterium. Int. J. Syst. Evol. Microbiol. 61:12651274 